\title{
Bahan Organik Total dan Kelimpahan Bakteri di Perairan Teluk Benoa, Bali
}

\author{
Ni Luh Eta Yuspita a*, I Dewa Nyoman Nurweda Putra a, Yulianto Suteja a \\ a Program Studi Ilmu Kelautan, Fakultas Kelautan dan Perikanan, Universitas Udayana, Bukit Jimbaran, Bali 80361, Indonesia \\ * Penulis koresponden. Tel.: +62-8135-3050-104 \\ Alamat e-mail: etayuspita@gmail.com
}

Diterima (received) 20 Juli 2017; disetujui (accepted) 10 September 2017; tersedia secara online (available online) 12 September

\begin{abstract}
Benoa Bay is semi-enclosed waters that have various activities. The existence of these activities will contribute to organic matter in the waters so that the effect on the presence of bacteria. This study aims to determine the total concentration of total organic matter (TOM) and bacterial abundance as well as its spatial and temporal distribution, and to determine the relationship of TOM concentration to bacterial abundance in the waters of Benoa Bay. Data collection is conducted on the surface of the waters in December 2016 to February 2017 when ebb conditions at 5 Benoa Bay water stations. Measurement of organic matter using permanganate test in titimetry based on standard methods SNI 06-6989.22-2004. Measurement of bacterial abundance using Total Plate Count (TPC) method. The TOM concentrations ranged from 63.20 to $65.10 \mathrm{mg} / \mathrm{l}$ and bacterial abundances ranged from 30 to $300 \mathrm{CFU} / \mathrm{ml}$. Spatial distribution of TOM concentration and bacterial abundance tends to be higher close to Suwung Landfills (TPA) activity, floating net cage cultivation (KJA) activity in Serangan waters, and Buaji river estuary and tend to be lower approaching Benoa harbor activity and waters further from those activities. The concentration of TOM and bacterial abundance in December 2016 to February 2017 have fluctuating values. Based on the interpretation of the correlation coefficient, the level of relationship between BOT concentration and bacterial abundance in the waters of Benoa Bay is quite strong.
\end{abstract}

Keywords: TOM; bacterial abundance; spatio-temporal; relationship analysis; Benoa Bay

\begin{abstract}
Abstrak
Teluk Benoa merupakan perairan semi tertutup yang memiliki berbagai macam aktivitas. Adanya aktivitas tersebut akan memberikan sumbangan terhadap bahan organik di perairan sehingga berpengaruh terhadap keberadaan bakteri. Penelitian ini bertujuan untuk mengetahui konsentrasi bahan organik total (BOT) dan kelimpahan bakteri serta persebarannya secara spasial dan temporal, dan untuk mengetahui hubungan konsentrasi BOT terhadap kelimpahan bakteri di perairan Teluk Benoa, Bali. Pengambilan data dilakukan di permukaan perairan pada bulan Desember 2016 hingga Februari 2017 saat kondisi pasang menuju surut di 5 stasiun perairan Teluk Benoa. Metode untuk analisis bahan organik menggunakan uji permanganat secara titimetri berdasarkan standard methods SNI 066989.22-2004. Analisis kelimpahan bakteri menggunakan metode Total Plate Count (TPC). Konsentrasi bahan organik berkisar antara 63,20- 65,10 mg/l dan kelimpahan bakteri berkisar antara $30-300 \mathrm{CFU} / \mathrm{ml}$. Persebaran spasial konsentrasi bahan organik dan kelimpahan bakteri cenderung lebih tinggi mendekati sumber aktivitas yaitu aktivitas TPA Suwung, budidaya keramba jaring apung (KJA) Serangan, serta muara sungai Buaji dan cenderung lebih rendah mendekati aktivitas pelabuhan Benoa dan perairan yang lebih jauh dari aktivitas-aktivitas tersebut. Konsentrasi bahan organik dan kelimpahan bakteri bulan Desember 2016 hingga Februari 2017 memiliki nilai flukuatif. Berdasarkan interpretasi koefisien korelasi, tingkat hubungan antara konsentrasi BOT dengan kelimpahan bakteri di perairan Teluk Benoa tergolong kuat.
\end{abstract}

Kata Kunci: BOT; kelimpahan bakter; spasio-temporal; analisis hubungan; Teluk Benoa 


\section{Pendahuluan}

Kawasan perairan Teluk Benoa merupakan kawasan perairan semi yang tertutup memiliki berbagai macam aktivitas (Risuana et al., 2017). Wilayah daratan kawasan Teluk Benoa digunakan sebagai Tempat Pembuangan Akhir (TPA), khususnya berlokasi pada Desa Suwung Kauh (Dewi et al., 2017). Pada wilayah perairannya terdapat aktivitas seperti pelabuhan Benoa dan budidaya keramba jaring Apung (Ernawati dan Dewi, 2016). Kawasan perairan Teluk Benoa juga menjadi muara bagi sejumlah sungai yang melintasinya.

Aktivitas-aktivitas tersebut diduga menyebabkan tingginya konsentrasi bahan organik di perairan Teluk Benoa. Hal ini didukung oleh beberapa hasil penelitian seperti penelitian yang dilakukan oleh Arbain et al. (2008) menyebutkan tingginya jumlah bahan organik pada air lindi Tempat Pembuangan Sampah Akhir (TPA) Suwung. Yuningsih et al. (2014) menyatakan tingginya komposisi bahan organik pada aktivitas keramba jaring apung (KJA) disebabkan karena kontribusi limbah dari pakan ikan, begitu juga dengan Sudirman et al. (2013) menyebutkan aktivitas pelabuhan dapat memberi masukan bahan organik yang tinggi dimungkinkan berasal dari kegiatan bengkel kapal dan juga air cucian ikan. Sedangkan menurut Kristiawan et al. (2014) muara sungai merupakan daerah dengan produktivitas tinggi dimana terdapat input zat-zat organik yang terbawa aliran sungai dari daratan.

Kristiawan et al. (2014) menyebutkan keberadaan bahan organik diperlukan dalam proses metabolisme mikroorganisme seperti bakteri sebagai sumber energi dalam perkembangan dan pertumbuhan mikroba. Kline et al. (2006) menyatakan tingginya kadar bahan organik di suatu perairan akan meningkatkan pertumbuhan mikroba. Kunarso (2011) menyebutkan kehadiran bakteri dalam ekosistem perairan laut berperan aktif sebagai dekomposer dalam proses mineralisasi bahan bahan organik.

Menurut Sutiknowati (2013) peranan bakteri terutama bakteri heterotrofik di lingkungan laut sangatlah vital sebagai dekomposer yang menguraikan material organik menjadi unsur hara esensial. Sebagaimana yang dinyatakan oleh Kunarso (1998) proses dekomposisi memainkan peran penting dalam ekosistem, terhambatnya proses ini akan berakibat pada terakumulasinya bahan organik yang tidak dapat dimanfaatkan langsung oleh produsen dan nutrien sebagai produk dekomposisi juga akan terhambat pasokannya.

Penelitian yang telah dilakukan sebelumnya oleh Kristiawan et al. (2014) yang menganalisis hubungan antara bahan organik total dengan kelimpahan bakteri di muara sungai menyebutkan bahwa semakin banyak konsentrasi bahan organik maka semakin banyak pula kelimpahan bakteri yang terkandung di perairan tersebut. Berdasarkan hal diatas maka penulis ingin meneliti bagaimana konsentrasi bahan organik total dan kelimpahan bakteri serta hubungan kedua parameter tersebut. Penelitian mengenai bahan organik total dan kelimpahan bakteri di perairan Teluk Benoa belum pernah dilakukan sebelumnya, maka penelitian ini penting untuk dilakukan sebagai informasi kondisi perairan yang nantinya dapat digunakan untuk menunjang perencanaan, pemanfaatan, serta pengelolaan wilayah perairan tersebut.

Penelitian ini bertujuan untuk mengetahui : konsentrasi bahan organik total serta persebarannya secara spasial dan temporal, kelimpahan bakteri serta persebarannya secara spasial dan temporal, dan hubungan konsentrasi bahan organik total dengan kelimpahan bakteri di perairan Teluk Benoa.

\section{Metode Penelitian}

\subsection{Waktu dan Tempat}

Pengambilan dilakukan sebanyak tiga kali yaitu pada periode sampling sebagai berikut :

Periode Pertama

: 12 Desember 2016

Periode Kedua

: 9 Januari 2017

Periode Ketiga

: 12 Februari 2017

Pengambilan sampel dilakukan setiap bulan pada pasang purnama (spring tide) saat kondisi pasang menuju surut.

Penelitian bertempat di perairan Teluk Benoa khususnya pada perairan antara Pelabuhan Benoa dan Pulau Serangan serta wilayah perairan antara Suwung Kangin dan Pulau Serangan di wilayah perairan Teluk Benoa (Gambar 1). Penentuan stasiun dilakukan dengan metode purposive sampling. Pada penelitian ini terdapat 5 stasiun penelitian yang disusun seperti Gambar 1. Stasiun 1 terletak di perairan dekat pelabuhan Benoa, stasiun 2 terletak pada perairan yang lebih jauh , 


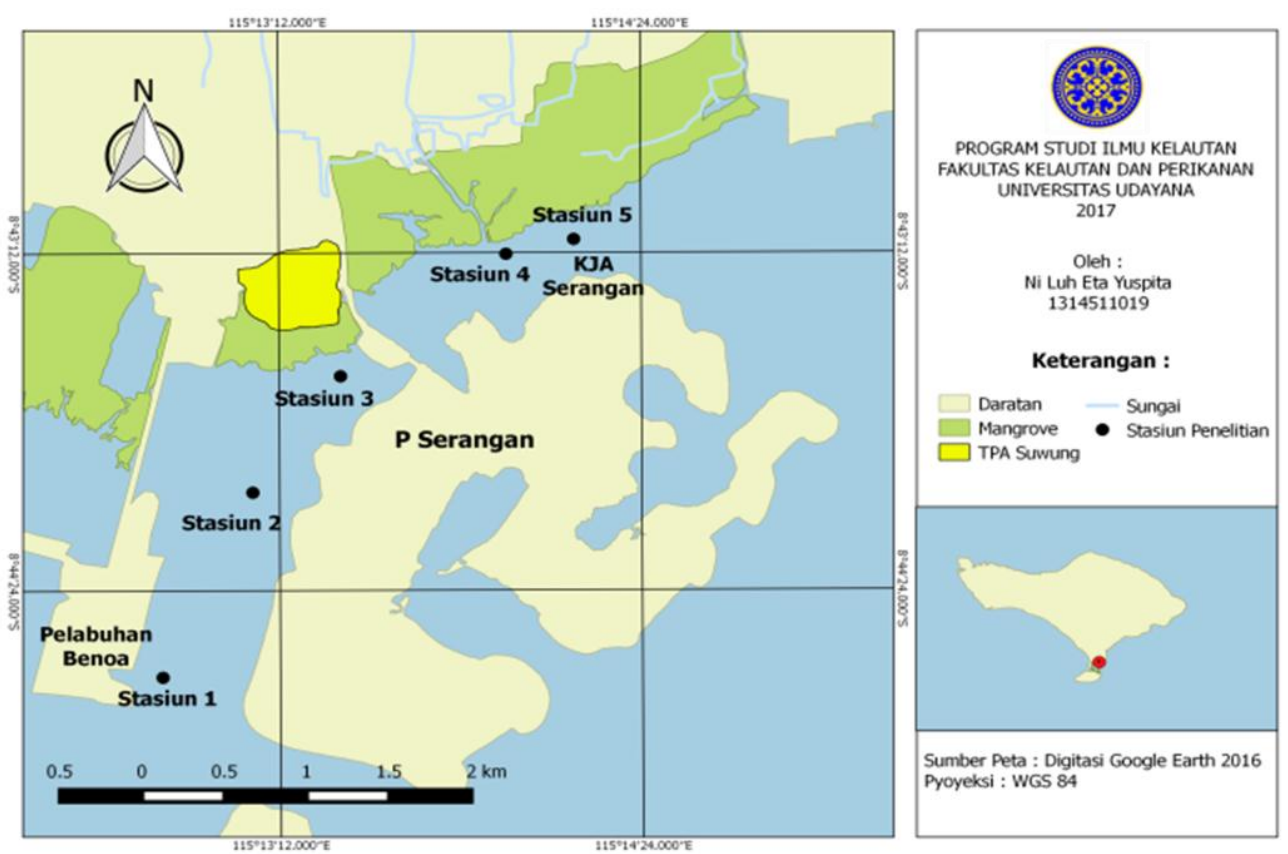

Gambar 1. Lokasi Penelitian di Perairan Teluk Benoa, Bali

stasiun 3 terletak pada perairan dekat TPA Suwung, stasiun 4 terletak di perairan sekitar muara sungai Buaji, serta stasiun 5 terletak di perairan dekat KJA Serangan. Analisis sampel dilakukan di Laboratorium Kesehatan Provinsi Bali.

\subsection{Pengumpulan Data}

Data yang dikumpulkan berupa data primer dan data sekunder. Data primer yang dikumpulkan diantaranya data parameter bahan organik total (BOT), kelimpahan bakteri, dan parameter fisikakimia perairan, sedangkan untuk data sekunder yaitu data curah hujan. Data primer dikumpulkan berdasarkan metode pengambilan data. Pengambilan sampel air laut untuk analisis bahan organik total dan total bakteri dilakukan di permukaan perairan berdasarkan standar metode pengambilan contoh SNI 06-2412-1991. Sampel kemudian disimpan di dalam cool box untuk selanjutnya dianalisis di Laboratorium Kesehatan Provinsi Bali. Sementara untuk pengukuran parameter fisika-kimia perairan diantaranya suhu, salinitas $\mathrm{pH}$, dan oksigen terlarut dilakukan secara in situ. Pengukuran parameter fisika-kimia perairan dilakukan sebanyak tiga kali pengulangan. Data curah hujan diperoleh dari Badan Meteorologi dan Geofisika (BMKG) Stasiun Tuban, Kabupaten Badung, Bali dengan mengunduh

data

http://dataonline.bmkg.go.id.

\subsection{Analisis Sampel}

\subsubsection{Bahan Organik Total (BOT)}

Metode pengukuran konsentrasi bahan organik menggunakan metode titimetri (SNI 06-6989.222004) yaitu sebanyak $50 \mathrm{ml}$ sampel dimasukkan kedalam Erlenmeyer $250 \mathrm{ml}$ kemudian ditambahkan $10 \mathrm{ml}$ larutan $\mathrm{H}_{2} \mathrm{SO}_{4}$ 4N. Larutan yang telah tercampur kemudian dipanaskan menggunakan hotplate sampai mendidih, lalu ditambahkan $10 \mathrm{ml}$ larutan $\mathrm{KMnO}_{4} \quad 0,01 \mathrm{~N}$. Larutan selanjutnya dididihkan tepat sepuluh menit lalu ditambahkan $10 \mathrm{ml}$ larutan asam oksalat $\mathrm{H}_{2} \mathrm{C}_{2} \mathrm{O}_{4} \quad 0,01 \mathrm{~N}$ dan didihkan kembali sampai warna merah hilang. Larutan kemudian dititrasi dengan larutan $\mathrm{KmnO}_{4}$ 0,01 N dalam keadan panas-panas.sampai terbentuk warna merah muda.

\subsubsection{Kelimpahan Bakteri}

Pemeriksaan kelimpahan bakteri menggunakan metode hitungan cawan (Total Plate Count) dengan media PCA (Plate Count Agar). Plate Count Agar atau yang juga sering disebut dengan Standard Methods Agar (SMA) merupakan sebuah media pertumbuhan mikroorganisme yang umum 
digunakan untuk menghitung jumlah bakteri (Addina, 2014).

Penumbuhan bakteri dilakukan dengan cara pengenceran berseri $10^{-1}, 10^{-2}, 10^{-3}$, dan $10^{-4}$. Pengenceran $10^{-1}$ dilakukan dengan cara memindahkan $1 \mathrm{ml}$ sampel air laut ke dalam tabung reaksi yang berisi $9 \mathrm{ml}$ larutan BPW (buffered peptone water), kemudian tabung reaksi dihomogenkan dengan menggunakan tube shaker. Selanjutnya, pengenceran $10^{-2}$ dilakukan dengan memindahkan $1 \mathrm{ml}$ larutan pengenceran $10^{-1} \mathrm{ke}$ dalam $9 \mathrm{ml}$ larutan BPW sehingga didapatkan pengenceran $10^{-2}$ kemudian dihomogenkan. Selanjutnya, dengan cara yang sama, dilakukan untuk memperoleh pengenceran $10^{-3}$ dan $10^{-4}$.

Setelah dilakukan pengenceran kemudian diambil $1 \mathrm{ml}$ dari sampel dan dari masing-masing pengenceran kemudian dimasukkan kedalam cawan petri steril yang telah diberi label sebelumnya. Masing-masing cawan petri tersebut kemudian dituangkan 10-15 ml media PCA. Setelah itu dihomogenkan isinya dengan menggoyangkan secara perlahan dan didiamkan pada suhu ruangan agar memadat. Setelah memadat, diinkubasi pada suhu $35-37^{\circ} \mathrm{C}$, selama 18-24 jam.

\subsection{Analisis Data}

\subsubsection{Bahan Organik Total (BOT)}

Rumus untuk menghitung konsentrasi bahan organik total menurut SNI 06-6989.22-2004 :

$B O T(m g / l)=\frac{[(10+a) \times f-10] \times 0,316 \times 1000}{b}$

Keterangan :

$a=$ ml dari $\mathrm{KMnO}_{4} 0,01 \mathrm{~N}$ yang dipakai

$f=$ faktor dari $\mathrm{KMnO}_{4} 0,01 \mathrm{~N}$

$b \quad=\mathrm{mL}$ sampel

$1 \mathrm{ml} \mathrm{KMnO}_{4}$ 0,01 $\mathrm{N}$ sesuai dengan 0,316 mg $\mathrm{KMnO}_{4}$. $f$ ditentukan dari hasil standarisasi $\mathrm{KMnO}_{4}$ dengan asam oksalat, dalam pengujian sampel ini faktornya adalah 1 .

\subsubsection{Kelimpahan Bakteri}

Kelimpahan bakteri dihitung berdasarkan jumlah koloni per unit atau colony forming unit (CFU) dalam setiap $1 \mathrm{ml}$. Kelimpahan bakteri dapat dihitung dengan menggunakan rumus :
$N(C F U / m l)=\frac{n}{\sum \text { penebaran }} \times \frac{1}{f p}$

Dimana :

$N$ = Kelimpahan bakteri

$n=$ jumlah koloni

$f p=$ faktor pengenceran

Apabila jumlah koloni yang dihitung terdapat pada pengenceran pertama maka faktor pengencerannya adalah $10^{-1}$ dan apabila terdapat pada pengenceran kedua maka faktor pengencerannya adalah $10^{-2} \mathrm{dst}$.

\subsubsection{Uji Statistik Korelasi dan Regresi}

Untuk mengetahui keeratan hubungan antara bahan organik dan kelimpahan bakteri dilakukan analisis korelasi dan regresi linear sederhana. Perhitungan analisis korelasi dan regresi linear sederhana ini menggunakan program computer Microsoft Excel 2010. Korelasi linear sederhana dinyatakan dalam rumus :

$r_{x y}=\frac{n\left(\sum x y\right)-\left(\sum x\right) \cdot\left(\sum y\right)}{\sqrt{n\left(\sum x 2\right)-\left(\sum x\right) 2 \sqrt{n\left(\sum y 2\right)}-\left(\sum y\right) 2}}$

Keterangan :

$\mathrm{r}_{\mathrm{xy}} \quad=$ Hubungan bahan organik dengan kelimpahan bakteri

$x=$ Konsentrasi bahan organik setiap stasiun

$y \quad=$ Kelimpahan bakteri setiap stasiun

Adapun interpretasi koefisien korelasi menurut Sugiyono (2014) ditunjukan pada Tabel 1.

Tabel 1

Interpretasi Koefisien Korelasi

\begin{tabular}{cl}
\hline Interval Koefisien & Tingkat Hubungan \\
\hline $0,00-0,199$ & Sangat Rendah \\
$0,20-0,399$ & Rendah \\
$0,40-0,599$ & Sedang \\
$0,60-0,799$ & Kuat \\
$0,80-1,000$ & Sangat Kuat \\
\hline
\end{tabular}

Sumber : Sugiyono, 2014

Regresi linear sederhana dinyatakan dalam rumus :

$y=a+b x$

Dimana :

$x=$ Konsentrasi bahan organik setiap stasiun 
$y=$ Nilai total bakteri setiap stasiun

$a=$ nilai konstanta

$b=$ koefisien arah regresi

\subsubsection{Interpolasi Inverse Distance Weighted (IDW)}

Persebaran spasial bahan organik total dan kelimpahan bakteri dilakukan menggunakan analisis interpolasi. Penelitian sebelumnya mengenai analisis persebaran spasial terhadap kelimpahan bakteri di perairan sudah pernah dilakukan oleh Palimirmo et al. (2016). Salah satu metode interpolasi yang telah banyak dilakukan pada bidang lingkungan perairan yaitu metode Inverse Distance Weighted (IDW). Rumus umum IDW (Saraswati et al., 2017) yaitu :

$\check{z}\left(S_{0}\right)=\frac{\sum_{i=1}^{n} \mathrm{z}\left(\mathrm{s}_{\mathrm{i}}\right) \cdot \mathrm{d}_{\mathrm{i} 0}^{-\mathrm{p}}}{\sum_{\mathrm{i}=1}^{\mathrm{n}} \mathrm{d}_{10}^{-\mathrm{p}}}$

Dimana :

So $\quad=$ lokasi estimasi

$\mathrm{n} \quad=$ jumlah tetangga (titik) terdekat

$\check{\mathrm{z}}\left(\mathrm{S}_{0}\right)=$ nilai lokasi prediksi

$\mathrm{z}\left(\mathrm{si}_{\mathrm{i}}\right)=$ nilai dari lokasi sampel, dengan $\mathrm{i}=1,2, \ldots, \mathrm{n}$

$\mathrm{p} \quad=$ eksponen yang menentukan bobot setiap prediksi

$\mathrm{d} \quad=$ jarak dari lokasi sampel si ke lokasi prediksi so

\section{Hasil dan pembahasan}

\subsection{Parameter Fisika-Kimia Perairan}

Suhu selama penelitian berkisar antara 28,39$31,08{ }^{\circ} \mathrm{C}$. Suhu bervariasi antar stasiun penelitian. Apriadi (2008) menyatakan aktivitas mikroorganisme seperti bakteri umumnya berlangsung optimal pada kisaran suhu $15-35{ }^{\circ} \mathrm{C}$.
Dengan demikian kisaran suhu optimal untuk kehidupan mikroorganisme seperti bakteri laut. Tabel 2 menunjukan kisaran nilai parameter fisikakimia perairan Teluk Benoa selama penelitian.

Salinitas berkisar antara 27,70 - 32,90 \%o. Palimirmo (2016) menjelaskan di dalam ekosistem laut selain bakteri yang dapat hidup pada lingkungan laut yaitu bakteri heterotrofik terdapat pula bakteri yang toleran terhadap air tawar yaitu bakteri halotoleran.

Nilai $\mathrm{pH}$ berkisar 7,68 - 8,05. Seperti yang disebutkan Sidharta (2000) bakteri tahan terhadap perubahan kecil $\mathrm{pH}$ dalam rentang 6-9 (Sidharta, 2000). Nilai pH optimum pertumbuhan bakteri terletak antara 6,5 dan 7,5. Nilai $\mathrm{pH}$ pada keseluruhan stasiun penelitian selama tiga bulan berada diatas nilai optimum untuk pertumbuhan bakteri namun masih berada pada rentangan yang baik untuk kehidupan bakteri.

Kisaran oksigen terlarut / DO selama penelitian yaitu 0,42 - 7,90 mg/l. Sidharta (2000) menyebutkan mikroorganisme seperti bakteri dapat hidup pada lingkungan dengan ketersediaan oksigen (bakteri aerob) hingga lingkungan tanpa oksigen (bakteri anaerob).

\subsection{Curah Hujan}

Berdasarkan data online curah hujan yang diperoleh dari Badan Meteorologi dan Geofisika (BMKG) diperoleh grafik intensitas curah hujan harian dari bulan Desember hingga Februari seperti pada Gambar 2. Intensitas curah hujan rata-rata pada bulan Desember sebesar 18,95 mm /hari, bulan Januari sebesar 11,42 mm/hari, dan bulan Februari sebesar 22,02 mm/hari. Intensitas curah hujan tertinggi terdapat pada bulan Desember dan intensitas terendah pada bulan

Tabel 2

Rentangan nilai parameter fisika-kimia perairan Teluk Benoa

\begin{tabular}{ccccc} 
& \multicolumn{4}{c}{ Parameter Lingkungan } \\
\cline { 2 - 5 } Stasiun & Suhu $\left({ }^{\circ} \mathrm{C}\right)$ & Salinitas (\%) & pH & DO (mg/l) \\
1 & $28.61-29.42$ & $30.00-31.59$ & $7.68-8.05$ & $7.14-7.90$ \\
2 & $29.12-31.08$ & $28.93-30.28$ & $7.76-8.00$ & $7.11-7.25$ \\
3 & $29.07-30.97$ & $27.70-29.60$ & $7.75-7.68$ & $0.42-5.89$ \\
4 & $28.85-30.23$ & $29.19-31.60$ & $7.76-7.84$ & $6.11-6.73$ \\
5 & $28.39-30.00$ & $28.58-32.90$ & $7.72-7.87$ & $3.56-6.53$ \\
\hline
\end{tabular}




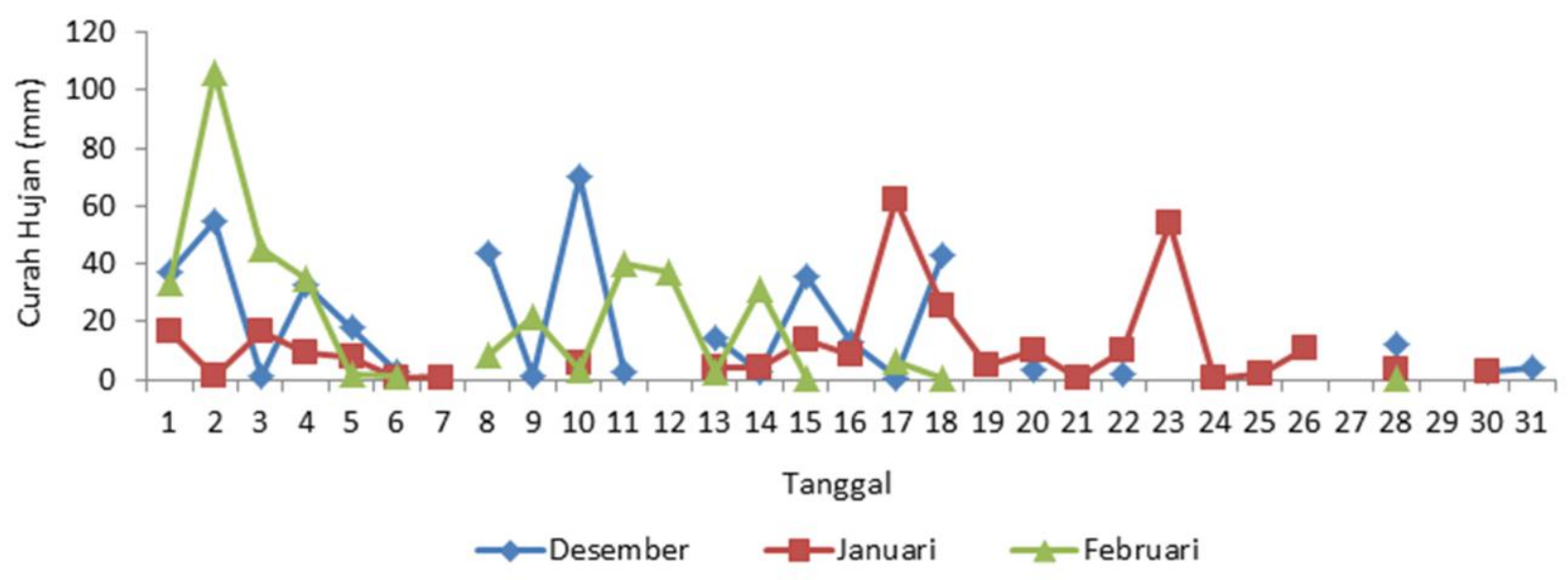

Gambar 2. Intensitas Curah Hujan Harian Bulan Desember 2016 - Februari 2017

Januari. Intensitas curah hujan dapat berpengaruh pada tinggi rendahnya masukan material organik ke perairan. Palimirmo et al. (2016), menyatakan adanya hujan menyebabkan tingginya limpasan material organik dari daratan ke perairan.

\subsection{Bahan Organik Total (BOT)}

Berdasarkan hasil analisis yang telah dilakukan selama 3 bulan diperoleh konsentrasi BOT berkisar antara 63,20 mg/1 - 65,10 mg/1 (Gambar 3). Hasil analisis di setiap bulannya diperoleh hasil yaitu pada bulan Desember konsentrasi rata-rata BOT sebesar 64,21 mg/l dengan konsentrasi BOT tertinggi sebesar $65,10 \mathrm{mg} / \mathrm{l}$ terdapat pada stasiun 3 dan terendah sebesar $63,20 \mathrm{mg} / \mathrm{l}$ terdapat pada stasiun 2. Pada bulan Januari, konsentrasi rata-rata BOT sebesar 63,71 $\mathrm{mg} / 1$ dengan dengan konsentrasi tertinggi sebesar $65,10 \mathrm{mg} / \mathrm{l}$ terdapat pada stasiun 3 dan konsentrasi terendah sebesar 63,20 mg/l terdapat pada stasiun 2, 4, dan 5. Pada bulan Februari konsentrasi rata-rata BOT sebesar 64,46 mg/l dengan konsentrasi tertinggi sebesar $65,10 \mathrm{mg} / 1$ terdapat pada stasiun 3 dan konsentrasi terendah sebesar $63,83 \mathrm{mg} / \mathrm{l}$ terdapat pada stasiun 2.

Konsentrasi BOT bervariasi antar stasiun penelitian. Stasiun 3 memiliki konsentrasi paling tinggi di bulan Desember, Januari, dan Februari. Konsentrasi BOT terendah terdapat pada stasiun 2 untuk bulan Desember, Januari, Februari dan stasiun 4 dan 5 untuk bulan Januari. Tingginya konsentrasi BOT di stasiun 3 diduga diakibatkan oleh masukan dari aktivitas TPA karena lokasi sampling yang berdekatan dengan TPA Suwung. Menurut Hardiwiyoto (1983) sampah domestik lebih banyak didominasi oleh bahan organik, oleh sebab itu TPA Suwung dapat memberikan masukan yang besar untuk bahan organik ke perairan. Hal ini didukung penelitian sebelumnya oleh Arbain et al. (2008) yang menyebutkan TPA Suwung memiliki kandungan bahan organik yang tinggi. Rendahnya konsentrasi BOT di stasiun 2 diduga karena stasiun 2 lebih jauh dari aktivitas pelabuhan Benoa, TPA Suwung, KJA Serangan, dan muara sungai Buaji. Selain stasiun 2, konsentrasi BOT terendah juga terdapat pada stasiun 4 (muara sungai Buaji) dan stasiun 5 (dekat KJA Serangan) pada bulan Januari, ini diduga akibat rendahnya intensitas curah hujan di bulan Januari. Hal ini dikuatkan oleh Lihan et al. (2008) yang menyebutkan tingginya suplai BOT yang masuk ke perairan sangat dipengaruhi oleh curah hujan, dimana curah hujan yang tinggi dapat meningkatkan beban zat hara masuk ke perairan.

Sebaran spasial BOT pada bulan Desember dan Februari memiliki pola yang sama yaitu BOT terkonsentrasi paling tinggi pada perairan yang berada di sekitar TPA Suwung, kemudian lebih rendah pada perairan di sekitar muara sungai Buaji dan KJA Serangan namun tidak lebih rendah dibandingkan perairan di sekitar pelabuhan Benoa. Perairan yang lebih jauh dari adanyanya aktivitas pelabuhan Benoa, TPA Suwung, KJA Serangan, dan muara sungai Buaji memiliki konsentrasi BOT paling rendah.

Sebaran spasial BOT di bulan Januari memiliki pola yang berbeda dengan bulan Desember dan Februari, dimana selain dari perairan yang lebih jauh dari sumber aktivitas konsentrasi BOT paling rendah juga terdapat pada perairan di sekitar muara sungai Buaji dan KJA Serangan. Diduga, 


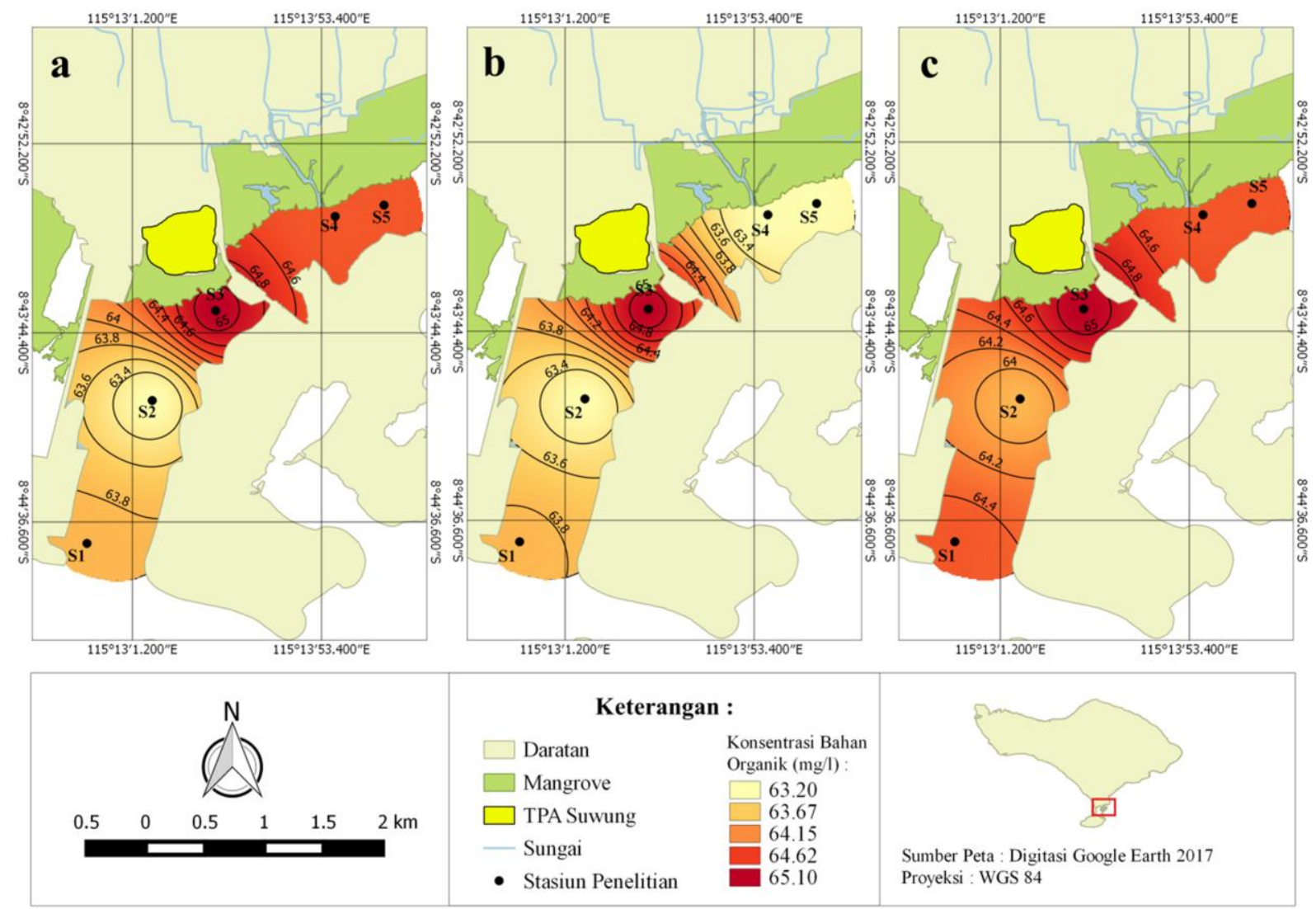

Gambar 3. Sebaran Spasial Bahan Organik : a. Bulan Desember 2016, b. Bulan Januari 2017, dan c. Bulan Februari 2017 di Perairan Teluk Benoa

rendahnya intensitas curah hujan di bulan Januari menyebabkan menurunnya masukan bahan organik yang terbawa melalui limpasan sungai sehingga konsentrasi BOT pada bagian perairan tersebut menjadi rendah. Hal ini sesuai dengan penelitian sebelumnya yang dilakukan oleh Palimirmo et al (2016), yang menyatakan adanya hujan menyebabkan tingginya limpasan material organik dari daratan ke perairan.

Secara temporal diperoleh konsentrasi rata-rata BOT tertinggi pada bulan Februari dan terendah pada bulan Januari. Hal ini diduga diakibatkan oleh perbedaan intesitas curah hujan pada masingmasing bulan. Intensitas curah hujan tertinggi di bulan Februari diduga menyebabkan tingginya BOT yang masuk ke perairan. Begitu pula sebaliknya rendahnya konsentrasi BOT di bulan Januari diduga akibat rendahnya intensitas curah hujan di bulan tersebut.

Konsentrasi BOT memiliki tren meningkat semakin mendekati sumber aktivitas diantaranya aktivitas pelabuhan Benoa, TPA Suwung, KJA Serangan, dan muara sungai Buaji. Adanya aktivitas seperti pelabuhan, aktivitas budidaya perikanan, TPA, dan aliran sungai memberikan masukan terhadap bahan organik ke perairan. Hal ini didukung oleh beberapa penelitian, seperti penelitian yang dilakukan Sudirman et al. (2013) menyebutkan bahwa aktivitas pelabuhan memberi masukan bahan organik dimungkinkan berasal dari kegiatan bengkel kapal dan juga air cucian ikan. Yuningsih et al. (2014) juga menyebutkan kegiatan budidaya ikan dalam keramba jaring apung dapat meningkatkan kandungan bahan organik yang dihasilkan dari sisa pakan maupun ekskresi ikan. Hadiwidodo et al. (2012) menyatakan, air lindi yang terbentuk dalam timbunan sampah di TPA melarutkan banyak sekali senyawa yang ada, sehingga memiliki kandungan pencemar khususnya zat organik yang sangat tinggi. Muara sungai juga memberikan masukan terhadap bahan organik ke perairan seperti pernyataan Kristiawan et al. (2014) menyebutkan bahwa sumber bahan organik berasal dari daratan dan terangkut ke perairan melalui aliran sungai sehingga di daerah muara terdapat sejumlah besar bahan organik. 


\subsection{Kelimpahan Bakteri}

Hasil analisis terhadap kelimpahan bakteri memperoleh hasil seperti pada gambar 4 . Kelimpahan bakteri selama tiga bulan penelitian berkisar antara $30-300 \mathrm{CFU} / \mathrm{ml}$. Analisis di setiap bulannya diperoleh hasil yaitu pada bulan Desember nilai rata-rata kelimpahan bakteri sebesar $177 \mathrm{CFU} / \mathrm{ml}$ dengan kelimpahan tertinggi pada stasiun 2 sebesar $300 \mathrm{CFU} / \mathrm{ml}$ dan kelimpahan terendah terdapat pada stasiun 2 yaitu sebesar 62 CFU/ml. Pada bulan Januari, diperoleh kelimpahan bakteri rata-rata sebesar $126 \mathrm{CFU} / \mathrm{ml}$ dengan kelimpahan tertinggi terdapat di stasiun 3 sebesar $186 \mathrm{CFU} / \mathrm{ml}$ dan terendah pada stasiun 2 yaitu sebesar $45 \mathrm{CFU} / \mathrm{ml}$. Pada bulan Februari, diperoleh kelimpahan bakteri rata-rata sebesar 130 $\mathrm{CFU} / \mathrm{ml}$ dimana stasiun 5 memiliki kelimpahan tertinggi sebesar $165 \mathrm{CFU} / \mathrm{ml}$ dan stasiun 2 memiliki kelimpahan terendah yaitu sebesar 30 $\mathrm{CFU} / \mathrm{ml}$.

Kelimpahan bakteri bervariasi antar stasiun, dimana stasiun 3 memiliki kelimpahan tertinggi untuk bulan Desember dan Januari dan stasiun 5 untuk bulan Februari. Kelimpahan bakteri terendah terdapat pada stasiun 2 pada bulan Desember, Januari, dan Februari. Tingginya kelimpahan bakteri pada stasiun 3 (dekat TPA Suwung) diduga disebabkan oleh tingginya konsentrasi BOT di stasiun tersebut. Hasil penelitian yang telah dilakukan oleh Kristiwan (2014) menyatakan bahwa konsentrasi BOT berkaitan erat dengan dengan kelimpahan bakteri, dengan semakin banyak konsentrasi BOT maka semakin banyak pula kelimpahan bakteri yang terkandung di perairan tersebut. Terlebih ditambahkan oleh Kurniawan (2006) dimana sampah merupakan wadah yang sangat baik untuk pembiakan jasad-jasad renik yaitu bakteri. Tingginya kandungan BOT di stasiun 3 juga berkaitan dengan parameter lingkungan yang diukur, diantaranya nilai $\mathrm{pH}$ dan $\mathrm{DO}$ yang paling rendah pada stasiun tersebut. Irawan et al. (2016) menyatakan nilai $\mathrm{pH}$ yang rendah dapat disebabkan oleh meningkatnya laju penguraian bahan organik oleh bakteri. Hal ini dikarenakan proses dekomposisi bahan organik menghasilkan $\mathrm{CO}_{2}$ yang dapat menurunkan $\mathrm{pH}$. Tingginya laju penguraian bahan organik oleh bakteri menyebabkan konsumsi oksigen semakin

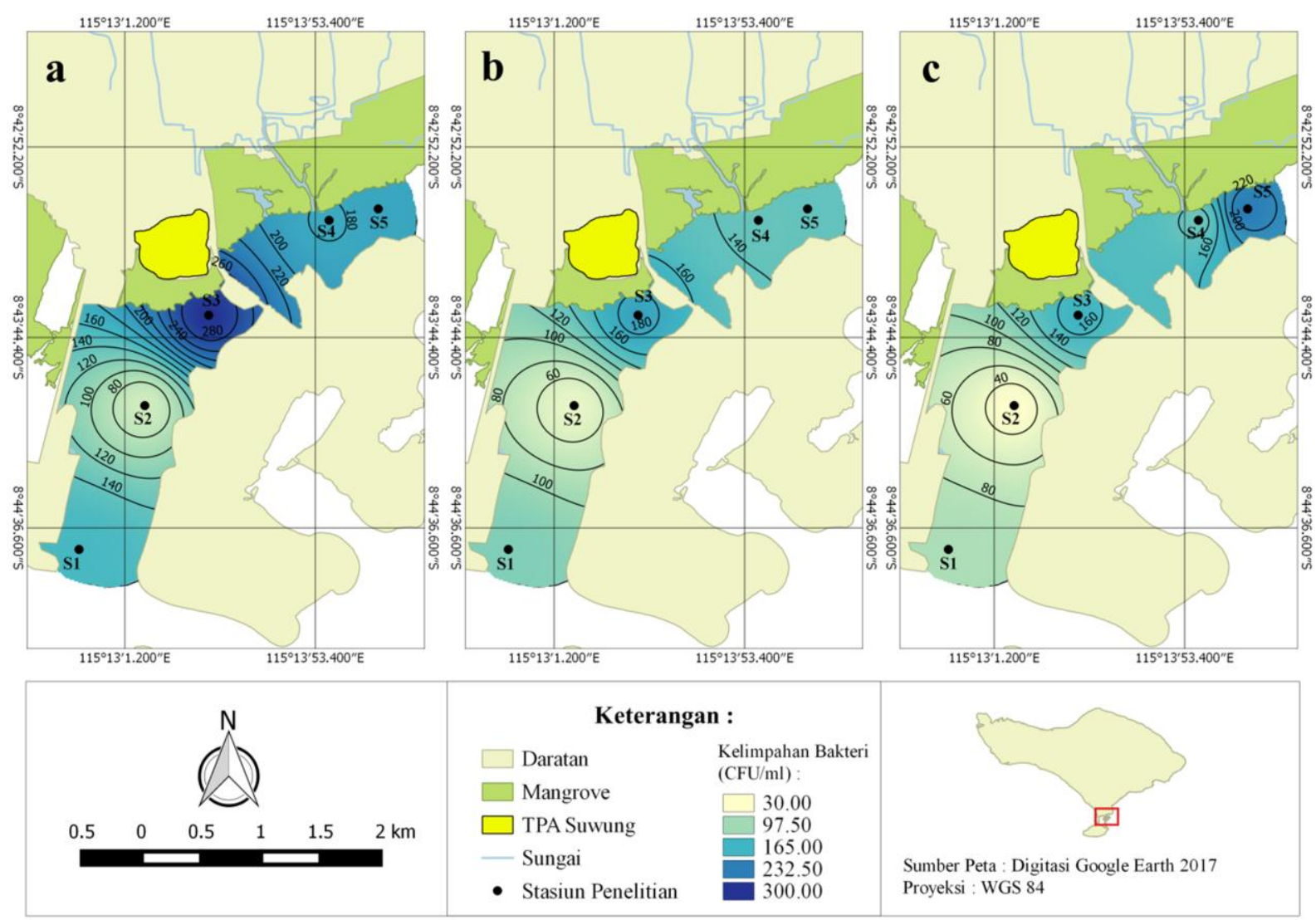

Gambar 4. Sebaran Spasial Kelimpahan Bakteri : a. Bulan Desember 2016, b. Bulan Januari 2017, dan c. Bulan Februari 2017 di Perairan Teluk Benoa 
bertambah sehingga DO di perairan akan semakin berkurang.

Stasiun 5 yang berada di perairan dekat KJA Serangan juga memiliki kelimpahan bakteri tertinggi pada bulan Februari. Hal ini diduga akibat meningkatnya konsentrasi BOT pada di stasiun 5 pada bulan tersebut. Kristiawan et al. (2014) menyatakan bahwa KJA memberikan kontribusi bahan organik yang tinggi melalui kotoran dan sisa pakan. Ditambahkan kembali oleh Yuningsih (2014) bahwa semakin banyak BOT dan dengan faktor lingkungan yang mendukung maka dapat menambah keberadaan bakteri di KJA Sementara untuk stasiun 2 memiliki kelimpahan bakteri terendah diduga akibat rendahnya pasokan BOT di perairan tersebut.

Sebaran spasial kelimpahan bakteri pada bulan Desember dan Januari memiliki pola yang sama yaitu kelimpahan paling tinggi pada perairan yang berada di sekitar TPA Suwung, kemudian lebih rendah pada perairan di sekitar muara sungai Buaji dan KJA Serangan namun tidak lebih rendah dibandingkan perairan di sekitar pelabuhan Benoa. Perairan yang lebih jauh dari aktivitas pelabuhan Benoa, TPA Suwung, KJA Serangan dan muara sungai Buaji memiliki kelimpahan bakteri paling rendah. Pola yang berbeda terjadi pada bulan Februari dimana kelimpahan bakteri tertinggi terkonsentrasi pada perairan di sekitar KJA Serangan.

Pola persebaran spasial bakteri bulan Desember sesuai dengan pola persebaran spasial BOT pada bulan tersebut. Kesesuian ini menunjukan BOT berpengaruh terhadap keberadaan bakteri di perairan Teluk Benoa. Pada bulan Januari dan Februari terjadi sedikit perbedaan pola antara persebaran bakteri dengan BOT. Pada bulan Januari kelimpahan bakteri pada perairan sekitar muara sungai Buaji dan KJA Serangan tidak paling rendah walaupun konsentrasi BOT pada bulan tersebut paling rendah, ini diduga terjadi karena penurunan konsentrasi BOT tidak langsung diikuti oleh penurunan jumlah bakteri. Pernyataan ini sesuai dengan hasil penelitian mengenai bioremediasi bahan organik oleh bakteri yang dilakukan Apriadi (2008) dimana konsentrasi bahan organik dari awal pengamatan telah mengalami penurunan akan tetapi jumlah bakteri mengalami peningkatan pada awal pengamatan, baru setelah pertengahan waktu pengamatan bakteri mulai mengalami penurunan mengikuti penurunan bahan organik hingga akhir pengamatan.

Begitu pula halnya dengan yang terjadi pada bulan Februari, pada perairan sekitar KJA Serangan memiliki kelimpahan bakteri tertinggi walaupun konsentrasi BOT pada bulan tersebut tidak paling tinggi, ini diduga terjadi karena bakteri mengalami pertumbuhan paling optimal. Pertumbuhan optimal dimungkinkan karena bakteri memasuki fase pertumbuhan log. Apriadi (2008) menyatakan fase pertumbuhan log atau $\log$ growth phase merupakan fase pertumbuhan bakteri yang terjadi secara cepat dengan laju metabolisme maksimum.

Variasi secara temporal menunjukan kelimpahan rata-rata bakteri tertinggi pada bulan Desember dan terendah pada bulan Januari.Walaupun konsentrasi BOT di bulan Desember bukan merupakan konsentrasi tertinggi, namun kelimpahan bakteri paling tinggi di bulan Desember. Hal ini diduga pada bulan Desember bakteri mengalami pertumbuhan paling optimal. Kelimpahan bakteri terendah pada bulan Januari sesuai dengan kandungan BOT paling rendah di bulan Januari.

Secara umum, kelimpahan bakteri memiliki tren yang serupa dengan tren konsentrasi BOT. Kelimpahan bakteri meningkat semakin mendekati sumber aktivitas yaitu aktivitas pelabuhan Benoa, TPA Suwung, KJA Serangan, dan muara sungai Buaji. Adanya aktivitas seperti pelabuhan, budidaya perikanan, TPA, dan aliran sungai dapat memberikan pasokan bahan organik ke perairan sehingga dapat memacu pertumbuhan bakteri yang memanfaatkan materi organik sebagai sumber nutrisinya. Hal ini didukung oleh Kristiwan (2014) yang menyatakan bahwa konsentrasi BOT berkaitan erat dengan dengan kelimpahan bakteri, dimana semakin banyak konsentrasi BOT maka semakin banyak pula kelimpahan bakteri yang terkandung di perairan.

\subsection{Hubungan Bahan Organik Total dengan Kelimpahan Bakteri}

Berdasarkan analisis korelasi konsentrasi BOT dengan kelimpahan bakteri di perairan Teluk Benoa pada bulan Desember hingga Februari diperoleh koefesien korelasi sebesar 0,646. Berdasarkan interpretasi koefisien korelasi, tingkat hubungan antara konsentrasi BOT dengan kelimpahan bakteri tergolong kuat. Hasil analisis 


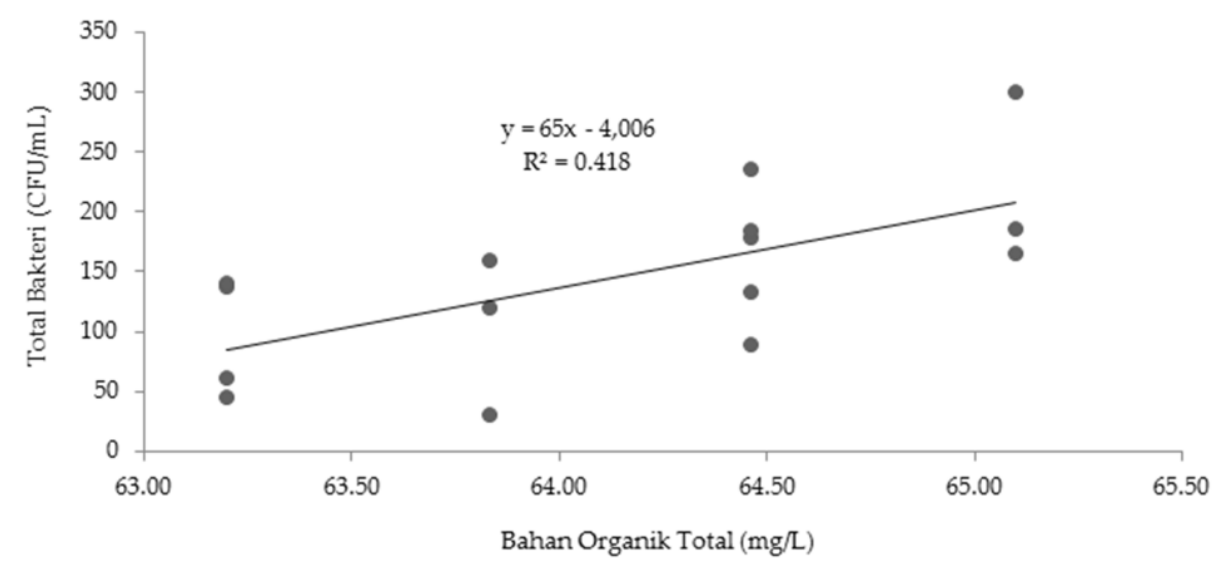

Gambar 5. Hubungan Bahan Organik Terhadap Kelimpahan Bakteri di Perairan Teluk Benoa

regresi linear sederhana untuk konsentrasi BOT dengan kelimpahan bakteri, diperoleh persamaan regresi $Y=64,729 X-4006,4$ dengan hubungan positif dan koefisien determinasi $\left(R^{2}\right)$ sebesar 0,418 artinya adanya pengaruh BOT terhadap total bakteri di perairan Teluk Benoa sebesar 41,8\%.

Hasil analisis hubungan BOT dan kelimpahan bakteri di perairan Teluk Benoa pada bulan Desember 2016 - Februari 2017 menunjukkan keterkaitan yang erat. Keberadaan bakteri di perairan Teluk Benoa) erat kaitannya dengan ketersediaan BOT sebagai sumber nutrisinya. Sebesar 41,8 \% kepadatan bakteri di Teluk Benoa dipengaruhi oleh BOT. Hal ini sesuai dengan penelitian yang dilakukan oleh Kristiawan et al. (2014) dan Marwan (2015) yang mendapatkan keeratan hubungan antara kandungan BOT dengan kelimpahan bakteri.

Sebagaimana yang disebutkan oleh Kunarso (2011) bahwa perbedaan terhadap jumlah kandungan bakteri sangat erat kaitannya dengan konsentrasi kandungan material organik yang tersedia dalam kolom air yang merupakan sumber nutrisi bagi bakteri. Ditambahkan kembali oleh Palimirmo (2016) peningkatan pasokan bahan organik dapat memacu proses kehidupan bakteri sehingga keberadaannya di perairan menjadi semakin banyak.

\section{Simpulan}

Kandungan bahan organik dari bulan Desember hingga Februari berkisar antara 63,20 mg/l - 65,10 $\mathrm{mg} / \mathrm{l}$. Secara umum, persebaran spasial bahan organik cenderung lebih tinggi pada perairan yang dekat dengan aktivitas TPA Suwung, KJA
Serangan, dan muara sungai Buaji, dan cenderung lebih rendah pada perairan dekat pelabuhan Benoa dan perairan yang lebih jauh dari adanya aktivitas-aktivitas tersebut. Konsentrasi bahan organk bulan Desember 2016 hingga Februari 2017 memiliki nilai yang fluktuatif dan rata-rata tertinggi adalah bulan Februari dan terendah pada bulan Januari.

Kepadatan total bakteri dari bulan Desember hingga Februari berkisar antara $30-300 \mathrm{CFU} / \mathrm{ml}$. Secara umum, persebaran spasial kelimpahan bakteri cenderung lebih tinggi pada perairan dekat aktivitas TPA Suwung, KJA Serangan, dan muara sungai Buaji dan cenderung lebih rendah pada perairan dekat aktivitas Pelabuhan Benoa dan dan perairan yang lebih jauh dari adanya aktivitasaktivitas tersebut. Kelimpahan bakteri bulan Desember 2016 hingga Februari 2017 memiliki nilai yang fluktuatif dan rata-rata tertinggi adalah bulan Desember dan terendah pada bulan Januari

Analisis hubungan menunjukan koefisien korelasi (r) sebesar 0,646 dan koefisien determinasi $\left(R^{2}\right)$ sebesar sebesar 0,418. Berdasarkan interpretasi koefisien korelasi, tingkat hubungan antara kandungan bahan organik dengan kelimpahan bakteri di perairan Teluk Benoa tergolong kuat dan bahan organik memberikan pengaruh terhadap kelimpahan bakteri sebesar $41,8 \%$. Gambar 5 menunjukan grafik hubungan linear positif, dimana konsentrasi BOT berbanding lurus dengan kelimpahan bakteri. Hal ini sejalan dengan hasil penelitian Purnomo et al. (2013) dan Putra et al. (2014) yang menganalisis hubungan antara total bakteri dengan bahan organik dengan total bakteri yang menunjukkan hubungan linear positif. 


\section{Ucapan terimakasih}

Ucapan terimakasih penulis sampaikan kepada reviewer yang telah memberikan masukan dalam penulisan jurnal. Penulis juga mengucapkan terima kasih kepada kepala UPT Laboratorium Kesehatan Provinsi Bali serta teman-teman dari program studi Ilmu Kelautan yang membantu penulis dalam melakukan penelitian.

\section{Daftar Pustaka}

Addina, G. (2014). Evaluasi Kadar Bakteri di Udara Dengan Menggunakan Media Plate Count Agar (PCA) Berdasarkan Tinggi Secara Vertikal di Departemen Bedah Mulut RSGMP FKG USU Dengan Metode Total Plate Count (TPC). Skripsi. Medan, Indonesia: Fakultas Kedokteran Gigi Universitas Sumatera Utara.

Apriadi, T. (2008). Kombinasi Bakteri dan Tumbuhan Air Sebagai Bioremediator dalam Mereduksi Kandungan Bahan Organik Limbah Kantin. Skripsi. Bogor, Indonesia: Departemen Manajemen Sumberdaya Perairan Fakutas Perikanan Dan Ilmu Kelautan Institut Pertanian Bogor.

Arbain, A., Mardana, N. K., \& Sudana, I. B. (2008). Pengaruh Air Lindi Tempat Pembuangan Akhir Sampah Suwung terhadap Kualitas Air Tanah Dangkal di Sekitarnya di Kelurahan Pedungan Kota Denpasar. Ecotrophic: Journal of Environmental Science, 3(2), $55-60$.

Dewi, N. N. D. K., Dirgayusa, I. G. N. P., \& Suteja, Y. (2017). Kandungan Nitrat dan Fosfat Sedimen serta Keterkaitannya dengan Kerapatan Mangrove di Kawasan Mertasari di Aliran Sungai TPA Suwung Denpasar, Bali. Journal of Marine and Aquatic Sciences, 3(2), 180-190.

Ernawati, N. M., \& Dewi, A. P. W. K. (2016). Kajian Kesesuaian Kualitas Air Untuk Pengembangan Keramba Jaring Apung Di Pulau Serangan, Bali. Ecotrophic: Journal of Environmental Science, 10(1), 75-80.

Hadiwidodo, M., Oktavian, W., Primadani, A. R., Parasmita, B. N., \& Gunawan, I. (2012). Pengolahan air lindi dengan proses kombinasi biofilter anaerobaerob dan wetland. Jurnal Presipitasi, 9(2), 84 -95.

Irawan, A., Jufri, Y., Zuraida. (2016). Pengaruh pemberian bahan organik terhadap perubahan sifat kimia andisol, pertumbuhan dan produksi gandum (Triticum eastivum L.). Jurnal Kawista, 1(1), 1-9.

Kristiawan, D., Widyorini, N., \& Haeruddin. (2014). Hubungan total bakteri dengan kandungan bahan organik dengan total bakteri di Muara Kali Wiso, Jepara. Diponegoro Journal of Maquares, 3(4), 24-33.

Kline, D. I., Kuntz, N. M., Breitbart, M., Knowlton, N \& Rohwer, F. (2006). Role of elevated organic carbon levels and microbial activity in coral mortality. Marine Ecology Progress Series, 314, 119-125.

Kunarso D. H. (1988). Peranan bakteri heterotrofik dalam ekosistem laut. Oseana, 8(4), 133-142.

Kunarso D. H. (2011). Kajian kesuburan ekosistem perairan laut Sulawesi Tenggara berdasarkan aspek bakteriologi. Jurnal Ilmu dan Teknologi Kelautan Tropis, 3(2), 32-47.

Kurniawan, B. (2006). Analisis Kualitas Air Sumur Sekitar Wilayah Tempat Pembuangan Akhir Sampah (Studi Kasus di TPA Galuga Cibungbulang Bogor). Skripsi. Bogor, Indonesia: Departemen Teknologi Industri Pertanian Fakultas Teknologi Pertanian Institut Pertanian Bogor.

Lihan, T., Saitoh, S. I., Iida, T., Hirawake, T., \& Iida, K. (2008). Satellite-measured temporal and spatial variability of the Tokachi River plume. Estuarine, Coastal and Shelf Science, 78(2), 237-249.

Marwan, A. H., Widyorini, N., \& Nitisupardjo, M. (2015). Hubungan total bakteri dengan kandungan bahan organik total di muara sungai Babon Semarang. Diponegoro Journal Of Maquares, 4(3), 170179.

Palimirmo, F. S., Damar, A., \& Effendi, H. (2016). Dinamika Sebaran Bakteri Heterotrofik di Teluk Jakarta. Jurnal Ilmu Pertanian Indonesia, 21(1), 26-34.

Purnomo, P. W., Nitisupardjo, M., \& Purwandari, Y. (2013). Hubungan antara total bakteri dengan bahan organik, $\mathrm{NO}_{3}$ dan $\mathrm{H}_{2} \mathrm{~S}$ pada lokasi sekitar eceng gondok dan perairan terbuka di Rawa Pening. Journal of Management of Aquatic Resources, 2(3), 85 - 95.

Putra, S. J. W., Nitisupardjo, M., \& Widyorini, N. (2014). Analisis hubungan bahan organik dengan total bakteri pada tambak udang intensif system semibioflok di BBPBAP Jepara. Diponegoro Journal of Maquares 3(3), 121-129.

Risuana, I. G. S., Hendrawan, I. G., \& Suteja, Y. (2017). Distribusi Spasial Total Padatan Tersuspensi Puncak Musim Hujan Di Permukaan Perairan Teluk Benoa, Bali. Journal of Marine and Aquatic Sciences, 3(2), 223232.

Saraswati, N. L. G. R. A., Arthana, I. W., \& Hendrawanb, I. G. (2017). Analisis Kualitas Perairan Pada Wilayah Perairan Pulau Serangan Bagian Utara Berdasarkan Baku Mutu Air Laut. Journal of Marine and Aquatic Sciences, 3(2), 163-170.

Sudirman, N., Husrin, S., \& Ruswahyuni, R. (2013). Baku mutu air laut untuk kawasan pelabuhan dan indeks pencemaran perairan di Pelabuhan Perikanan Nusantara Kejawanan, Cirebon. Jurnal Saintek Perikanan, 9(2), 14-22.

Sugiyono. (2014). Metode penelitian pendidikan pendekatan kuantitatif, kualitatif dan RED. Bandung, Indonesia: Alfabeta.

Sutiknowati, L. I. (2013). Mikroba parameter kualitas perairan P. Pari untuk upaya pembesaran biota 
budidaya. Jurnal Ilmu dan Teknologi Kelautan Tropis, 5(1), 204-218.

Yuningsih, H. D., Soedarsono, P., \& Anggoro, S. (2014).

Hubungan bahan organik dengan produktivitas perairan pada kawasan tutupan eceng gondok, perairan terbuka dan keramba jaring apung di Rawa Pening Kabupaten Semarang Jawa Tengah. Diponegoro Journal of Maquares, 3(1), 37 - 43.

(C) 2017 by the authors; licensee Udayana University, Indonesia. This article is an open access article distributed under the terms and conditions of the Creative Commons Attribution license (http://creativecommons.org/licenses/by/3.0/). 